\title{
HEALTH BELIEF MODEL ON DETERMINANT OF CARIES PREVENTIVE BEHAVIOR: EVIDENCE ON KLATEN CENTRAL JAVA
}

\author{
Dewi Mustika Ratih' ${ }^{1}$, Yulia Lanti Retno Dewi'), Bhisma Murti') \\ ${ }^{1)}$ Masters Program in Public Health, Universitas Sebelas Maret \\ 2)Faculty of Medicine, Universitas Sebelas Maret
}

\begin{abstract}
Background: Early childhood caries can be prevent by promoting dental health behavior in school. The purpose of this study was to examine the determinants of caries preventive behavior in primary school children using Health Belief Model.

Subjects and Method: This was a cross-sectional study. The study was conducted at 25 primary schools in Klaten, Central Java, in September 2019. A total sample of 200 primary school students was selected for this study randomly. The dependent variable was dental caries preventive behavior. The independent variables were perceived susceptibility, perceived seriousness, percevied benefit, and perceived barrier. The data were collected by questionnaire and analyzed by a multiple logistic regression.

Results: Dental caries preventive behavior increased with perceived susceptibility ( $\mathrm{b}=$ $0.88 ; 95 \% \mathrm{CI}=0.10$ to $1.66 ; \mathrm{p}=0.026)$, perceived seriousness $(\mathrm{b}=1.64 ; 95 \% \mathrm{CI}=0.53$ to $2.75 ; \mathrm{p}=0.004)$, and perceived benefit $(\mathrm{b}=1.05 ; 95 \% \mathrm{CI}=0.17$ to $1.93 ; \mathrm{p}=0.190)$. Dental caries preventive behavior decreased with perceived barrier $(b=-1.53 ; 95 \% \mathrm{CI}=-2.81$ to $0.26 ; \mathrm{p}=0.018$ ).

Conclusion: Dental caries preventive behavior increases with perceived susceptibility, perceived seriousness, and perceived benefit. Dental caries preventive behavior decreased with perceived barrier.
\end{abstract}

Keywords: dental caries, preventive behavior, primary school students, health belief model

\section{Correspondence:}

Dewi Mustika Ratih, Masters Program in Public Health, Universitas Sebelas Maret. Jl. Ir. Sutami 36A, Surakarta 57126, Central Java, Indonesia. Email: dewiratih1822@gmail.com. Mobile: +625640041822 . 